\title{
Gastrointestinal responses of rats fed on white and wholemeal breads: complex carbohydrate digestibility and the influence of dietary fat content
}

\author{
BY FIONA B. KEY* AND J. C. MATHERS† \\ Department of Biological and Nutritional Sciences, University of Newcastle upon Tyne, \\ Newcastle upon Tyne NEI $7 R U$
}

(Received 4 November 1991-Accepted 25 March 1992)

\begin{abstract}
To obtain quantitative information on the digestibility of the non-starch polysaccharides (NSP) fraction of white and wholemeal breads, rats were fed on diets in which freeze-dried bread (white, wholemeal or mixtures of the two) provided all the complex carbohydrates. In a second experiment the possibility that dietary fat concentration might influence NSP digestibility was tested by feeding diets containing 30 or $170 \mathrm{~g}$ maize oil $/ \mathrm{kg}$ and either white or wholemeal bread. Multiple linear regression analysis provided little evidence of associative effects of dietary components on NSP digestibility and in the two experiments digestibilities of NSP for white and wholemeal breads were $0.77-0.82$ and $0.47-0.52$ respectively. Xylose- and arabinose-containing polymers were better digested than was cellulose for both breads. Replacing white by wholemeal bread markedly increased the molar proportion of butyrate in caecal volatile fatty acids at the expense of acetate. This was associated with greater flows of organic matter to the large bowel (LB) and a reduction in caecal transit time (Expt 2). There was little detectable effect of dietary maize oil concentration on NSP digestibility or on LB fermentation. All breads contained some starch resistant to pancreatic $\alpha$-amylase $(E C 3.2 .1$.1) without previous treatment with dimethyl sulphoxide. The digestibility of this starch fraction was not significantly different from 1.0 for all diets except that containing wholemeal bread and the higher maize oil concentration where the apparent digestibility was 0.89 .
\end{abstract}

White and wholemeal bread: Dietary fat: Complex carbohydrate digestibility: Large bowel fermentation: Rat

Classical studies comparing the nutritive values of white and wholemeal breads in man were reported 50 years ago with particular attention to the utilization of minerals (McCance \& Widdowson, $1942 a, b)$ and the digestibility of major food fractions including so-called 'crude fibre' (Macrae et al. 1942). Whilst these studies established that 'crude fibre' was digested to some extent in man, with much greater digestibility for white bread where the crude fibre is mainly 'cell envelopes' compared with wholemeal bread rich in the 'woody fibre in the bran' (Macrae et al. 1942), the measurement of this carbohydrate fraction was relatively difficult. Improvements in food carbohydrate chemistry (Southgate, 1969) and, in particular, the direct chemical assay of non-starch polysaccharides (NSP) (Englyst \& Cummings, 1984) now make it possible to determine, with confidence, the digestibilities of the NSP fraction in man (Stephen et al. 1986) and other animals (Goodlad \& Mathers, 1990, 1991).

\footnotetext{
*Present address: MRC Institute of Hearing Research, University of Nottingham, University Park, Nottingham.

$\dagger$ For reprints.
} 
The present studies were designed to obtain quantitative information on the digestibility of the NSP fraction and its constituent sugars in white and wholemeal breads using the rat. The breads supplied the only complex carbohydrates in the experimental diets, with mixtures of the breads, in addition to each type separately, being fed to test the hypothesis that there is no interaction between these foods in digestibility of NSP. Since it was anticipated that the supply of additional NSP in wholemeal bread would influence large bowel (LB) metabolism (Cheng et al. 1987; Goodlad \& Mathers, 1990; Mathers et al. 1990), detailed studies of caecal fermentation were carried out.

Whilst conventional rat diets are relatively low in fat, human diets, particularly in affluent Western countries, may provide $40 \%$ of dietary energy as fat (Department of Health and Social Security, 1984). To determine whether the concentration of dietary fat influences NSP digestibility or LB fermentation, a second experiment was carried out with diets containing 30 or $170 \mathrm{~g}$ maize oil $/ \mathrm{kg}$ and either white or wholemeal bread. In addition to the measurements made in the first experiment, caecal transit time (TT) and organic matter (OM) fermentation in the LB were measured (in an attempt to explain changes in caecal fermentation) and portal volatile fatty acid (VFA) concentrations were determined as an indication of changes in fermentation endproduct supply to the liver.

Brief accounts of parts of the present study have been presented (Key \& Mathers, 1987 , 1988).

MATERIALS AND METHODS

Two experiments were carried out using similar animals, diets and experimental procedures.

\section{Animals}

For each experiment, twenty-four male Wistar rats were purchased (A. Tuck \& Sons, Battlesbridge, Essex), housed in stock cages (four rats per cage) and given ad lib. access to a stock diet (41B; Oxoid Ltd, Basingstoke, Hants.) for a pre-experimental period of $7 \mathrm{~d}$. Thereafter, rats were randomly allocated to individual Perspex and stainless steel metabolism cages (Thompson, 1970) which permitted complete separation and collection of urine and faeces. Six animals were allocated at random to each experimental diet.

\section{Diet}

Fresh standard sliced bread, white and wholemeal (Robertsons Bakers, Carlisle, Cumbria), was frozen at $-20^{\circ}$ within $4 \mathrm{~h}$ of delivery and subsequently freeze-dried. When dry the bread was ground to pass a $1 \mathrm{~mm}$ screen and stored at $-20^{\circ}$ until incorporated into the diets.

Expt 1. Four diets were formulated (Table 1) in which freeze-dried bread provided $900 \mathrm{~g}$ air-dry matter $/ \mathrm{kg}$ as all white bread (W) changing in equal steps to all wholemeal bread (B). The remainder of the diet was identical and contained no complex carbohydrates. Each rat was offered $20 \mathrm{~g}$ air-dry diet at 10.00 hours daily with any uneaten food removed, dried and weighed. Water was available $a d l i b$.

Expt 2. This experiment was designed to investigate the effect of dietary fat content in addition to bread type. The two 'low-fat' diets (W and B) were identical with those used in Expt 1 whilst the two 'high-fat' diets (WF and BF) contained $170 \mathrm{~g}$ maize oil $/ \mathrm{kg}$, largely at the expense of bread (Table 1). To maintain similar intakes of energy and of protein, 20 and $17 \mathrm{~g} / \mathrm{d}$ of the low- and high-fat diets respectively were offered with the high-fat diets containing a higher concentration of casein and amino acids mix.

$\mathrm{Cr}_{2} \mathrm{O}_{3}(2 \mathrm{~g} / \mathrm{kg})$ was added to the diets in Expt 2 as a digesta flow marker to enable estimation of digesta flow rates, especially at the terminal ileum, and of caecal transit times (Goodlad \& Mathers, 1990). 
Table 1. Formulation $(\mathrm{g} / \mathrm{kg})$ of experimental diets

\begin{tabular}{|c|c|c|c|c|c|c|c|c|}
\hline \multirow[b]{2}{*}{ Diet code. } & \multicolumn{4}{|c|}{ Expt 1} & \multicolumn{4}{|c|}{ Expt 2} \\
\hline & W & WB & BW & B & W & WF & B & $\mathrm{BF}$ \\
\hline White bread* & 900 & 600 & 300 & 0 & 900 & 750 & 0 & 0 \\
\hline Wholemeal bread* & 0 & 300 & 600 & 900 & 0 & 0 & 900 & 750 \\
\hline Maize oil & 30 & 30 & 30 & 30 & 30 & 170 & 30 & 170 \\
\hline Casein + amino acid mix $\dagger$ & 30 & 30 & 30 & 30 & 30 & 50 & 30 & 50 \\
\hline Vitamin + mineral mix + & 40 & 40 & 40 & 40 & 40 & $30 \S$ & 40 & 308 \\
\hline
\end{tabular}

* Supplied by Robertsons Bakers, Carlisle, Cumbria. Freeze-dried and ground to pass a $1 \mathrm{~mm}$ screen.

$\dagger$ Casein-D-lysine-L-methionine $(10: 2: 1$, by wt).

\$ Contained (g/kg premix): $\mathrm{CaH}_{2} \mathrm{PO}_{4} 300, \mathrm{KCl} 100, \mathrm{MnSO}_{4} \cdot 4 \mathrm{H}_{2} \mathrm{O} 3 \cdot 5, \mathrm{FeSO}_{4} .7 \mathrm{H}_{2} \mathrm{O} 1 \cdot 25, \mathrm{CuCl}_{2} 0 \cdot 2, \mathrm{KIO}_{3}$ 0.006 , choline chloride 34 and (mg/kg premix) Rovimix $\mathrm{AD}_{3}$ (Roche) 250, Rovimix E50 (Roche) 1500, menadione 12.5 , folic acid 15 , calcium pantothenate 110 , riboflavin 75 , thiamine hydrochloride 55 , pyridoxine hydrochloride 180 , cyanocobalamin 1 plus sucrose to make $1 \mathrm{~kg}$.

$\$$ Contained approximately 1.75 times concentrations of vitamins and minerals (at the expense of sucrose) to compensate for lower amounts of premix supplied and lower bread intake.

\section{Experimental protocol}

After an adaptation period of $7 \mathrm{~d}$, faeces were removed daily, frozen and pooled for two subsequent $7 \mathrm{~d}$ balance periods. Urine was collected into vessels containing $5 \mathrm{ml} 6 \mathrm{M}-\mathrm{H}_{2} \mathrm{SO}_{4}$ over the same periods. Animals were weighed at $7 \mathrm{~d}$ intervals.

Expt 1. Rats were killed by chloroform overdose. The abdomen was opened by a midline incision and the caecum removed and weighed. Caecal digesta $\mathrm{pH}$ was measured immediately and directly using a microelectrode attached to a standard $\mathrm{pH}$ meter and samples were taken for VFA and dry matter (DM) determinations. The caecum was gently washed free of digesta using saline $(9 \mathrm{~g} \mathrm{NaCl} / 1)$, blotted dry and weighed. Two faecal pellets from the terminal colon were removed for DM determination.

Expt 2. Rats were anaesthetized with diethyl ether, the abdomen was opened and blood removed from the portal vein $(1-3 \mathrm{ml})$ and the heart $(2-5 \mathrm{ml})$. Caecal and colonic samples were taken as described for Expt 1.

\section{Analytical methods}

$\mathrm{N}$ determinations on diets, faeces and urine were made by a Kjeldahl procedure, $\mathrm{Cr}_{2} \mathrm{O}_{3}$ and VFA in caecal digesta as described by Mathers et al. (1990) and 3-hydroxybutyrate (3OHB) enzymically in deproteinized blood (Lloyd et al. 1978). Blood VFA were determined by gas-liquid chromatography as described by Goodlad \& Mathers (1990). Dietary and faecal NSP were analysed as described by Englyst \& Cummings (1984) and resistant starch (RS) by omitting the dimethyl sulphoxide (DMSO) addition step. The fraction of RS measured in this way is largely retrograded amylose $\left(\mathrm{RS}_{3}\right.$; Englyst \& Kingman, 1990).

\section{Experimental designs, calculations and statistical analyses}

Expt 1. The experiment was designed as a single factor study with four treatments (diets) and six replicates (rats) per diet. Values were examined by one-way analysis of variance and orthogonal polynomials used to describe responses to differences in concentrations of white and wholemeal bread in the diets.

Expt 2. Bread type and dietary fat concentration were considered as separate factors each present at two levels and with six replicates per diet. Values were examined by two-factor analysis of variance. 
For both experiments, results are presented as means for each diet with their standard errors based on the between-animals within-diets variations with $20 \mathrm{df}$.

Separate estimates of apparent digestibility of polysaccharides of white and wholemeal breads were obtained by a multiple linear regression (MLR) technique (Zar, 1974) first outlined by Key \& Mathers (1990); a similar approach was adopted by Van Dokkum et al. (1983) to obtain estimates of the digestibility of 'fibre' in breads added to a basal diet. In the present study the following MLR model was used:

$$
Y=\alpha_{1} X_{1}+\alpha_{2} X_{2}+\alpha_{3} X_{1} X_{3},
$$

where $Y$ was NSP output in faeces, $X_{1}$ and $X_{2}$ were intakes of NSP from white and wholemeal breads respectively, $X_{3}$ has the value of 0 or 1 when wholemeal bread was absent from or present in the diet respectively, $\alpha_{1}$ and $\alpha_{2}$ are the coefficients of indigestibility for NSP in white and wholemeal breads respectively, and $\alpha_{3}$ is the additional effect of wholemeal bread presence on white-bread NSP digestibility.

Computations were made using the Statgraphics (STSC Inc., Rockville, Maryland, USA) package. Apparent digestibilities were calculated by subtracting the appropriate coefficients of indigestibility from unity.

In Expt 2, caecal transit time was calculated as the amount of $\mathrm{Cr}_{2} \mathrm{O}_{3}$ recovered in that organ divided by $\mathrm{Cr}_{2} \mathrm{O}_{3}$ intake rate (Goodlad \& Mathers, 1990); for further discussion of methodology, see Mathers \& Dawson (1991).

\section{RESULTS}

Expt I

Food intake and growth. There was a significant $(P<0.05)$ linear decline in weight gain with increasing proportion of wholemeal bread in the diet which could, in part, be explained by lower DM intakes particularly for diets WB and BW (Table 2). Of probably greater importance, however, was the strongly linear decrease in digestibility of DM as wholemeal replaced white bread in the diet. Whilst there were no significant $(P>0.05)$ between-diets differences in $\mathbf{N}$ retention suggesting that lean tissue gain was unaffected by diet, these estimates were associated with a relatively large SEM (Table 2) so that it should not be concluded unequivocally that diet did not influence $\mathrm{N}$ retention. Faecal $\mathrm{N}$ output increased linearly $(P<0.001)$ with increasing wholemeal bread in the diet.

Caecal fermentation. Variation in the type of bread in the diet had no significant effects on caecal mass, on caecal tissue weight or on the mass of wet digesta in this organ (Table $3)$. However, the proportion of $\mathrm{DM}$ in caecal digesta increased linearly $(P<0.001)$ as wholemeal bread intake increased at the expense of white. The proportion of DM in distal contents was unaffected by diets with an overall mean of 0.40 (SEM $0 \cdot 015$ ).

The concentration of total VFA in caecal contents tended to fall as white bread was replaced by wholemeal bread in the diet but the changes were not statistically significant $(P>0.05)$ and there were no detectable accompanying changes in caecal digesta $\mathrm{pH}$ (Table 4). However, diet had very marked effects on the molar proportions of individual VFA with increasing wholemeal bread intake associated with strong linear falls in acetate and compensatory increases in butyrate and, to a much lesser extent, isobutyrate.

Digestibility of NSP. The MLR model provided a good description of the relationships between intakes of NSP (and its components) from the breads and faecal outputs, $R^{2}>$ 0.94 except for mannose $(0.76)$, see Table 5. There was no convincing evidence of an associative effect of the presence of wholemeal bread on the digestibility of NSP in white bread as measured by the parameter $\alpha_{3}$ (Table 5), although for some components, e.g. cellulose, $\alpha_{3}$ was numerically large and was statistically significant for mannose $(P<0.01)$. 
Table 2. Expt 1. Dry matter $(D M)$ intakes and faecal output, weight gain and aspects of nitrogen metabolism by rats given diets containing various proportions of white and wholemeal breads

(Means for six rats per diet)

\begin{tabular}{|c|c|c|c|c|c|c|c|c|}
\hline \multirow{2}{*}{$\begin{array}{r}\text { Wholemeal bread in diet }(\mathrm{g} / \mathrm{kg}) \dagger \ldots \\
\text { Diet code } \ldots\end{array}$} & \multirow{2}{*}{$\stackrel{0}{W}$} & \multirow{2}{*}{$\begin{array}{l}300 \\
\text { WB }\end{array}$} & \multirow{2}{*}{$\begin{array}{l}600 \\
\text { BW }\end{array}$} & \multirow{2}{*}{$\begin{array}{c}900 \\
\text { B }\end{array}$} & \multirow{2}{*}{$\begin{array}{l}\text { SE of } \\
\text { mean }\end{array}$} & \multicolumn{3}{|c|}{$\begin{array}{c}\text { Statistical } \\
\text { significance } \\
\text { of dietary } \\
\text { effects }\end{array}$} \\
\hline & & & & & & Lin & Quad & Dev \\
\hline DM intake $(\mathrm{g} / 7 \mathrm{~d})$ & 117 & 108 & 106 & 114 & $2 \cdot 6$ & NS & $* *$ & NS \\
\hline Wt gain $(g / 7 d)$ & 30 & 26 & 25 & 24 & $1 \cdot 6$ & * & NS & NS \\
\hline Faecal DM output $(\mathrm{g} / 7 \mathrm{~d})$ & $5 \cdot 2$ & 68 & $9 \cdot 0$ & 11.9 & $0 \cdot 29$ & $* * *$ & NS & NS \\
\hline DM indigestibility & $0 \cdot 044$ & 0.063 & $0 \cdot 085$ & $0 \cdot 104$ & $0 \cdot 0014$ & $* * *$ & NS & NS \\
\hline $\mathrm{N}$ intake $(\mathrm{g} / 7 \mathrm{~d})$ & $2 \cdot 44$ & $2 \cdot 34$ & $2 \cdot 37$ & $2 \cdot 69$ & 0.058 & $* *$ & $* *$ & NS \\
\hline Faecal $N$ output $(\mathrm{g} / 7 \mathrm{~d})$ & $0 \cdot 31$ & $0 \cdot 36$ & $0 \cdot 40$ & 0.48 & $0 \cdot 020$ & $* * *$ & NS & NS \\
\hline Urinary $\mathrm{N}$ output $(\mathrm{g} / 7 \mathrm{~d})$ & 1.23 & $1 \cdot 17$ & $1 \cdot 25$ & $1 \cdot 42$ & 0.074 & NS & NS & NS \\
\hline $\mathrm{N}$ retention $(\mathrm{g} / 7 \mathrm{~d})$ & $0 \cdot 89$ & 0.82 & 0.72 & 0.79 & 0.065 & NS & NS & NS \\
\hline
\end{tabular}

NS, not significant; Lin, Quad and Dev, linear, quadratic and deviations from linear and quadratic effects of wholemeal bread content of diet respectively.

${ }^{*} P<0 \cdot 05, * * P<0.01, * * * P<0.001$.

$\dagger$ For details of diet composition, see Table 1 .

Table 3. Expt 1. Caecal organ, tissue and digesta masses and proportions of dry matter (DM) in caecal and colonic contents from rats given diets containing various proportions of white and wholemeal breads

(Means for six rats per diet)

\begin{tabular}{|c|c|c|c|c|c|c|c|c|}
\hline \multirow{2}{*}{$\begin{array}{r}\text { Wholemeal bread in diet }(\mathrm{g} / \mathrm{kg}) \dagger \ldots \\
\text { Diet code... }\end{array}$} & \multirow{2}{*}{$\begin{array}{c}0 \\
\mathbf{W}\end{array}$} & \multirow{2}{*}{$\begin{array}{l}300 \\
W B\end{array}$} & \multirow{2}{*}{$\begin{array}{l}600 \\
B W\end{array}$} & \multirow{2}{*}{$\begin{array}{c}900 \\
B\end{array}$} & \multirow{2}{*}{$\begin{array}{l}\text { SE of } \\
\text { mean }\end{array}$} & \multicolumn{3}{|c|}{$\begin{array}{c}\text { Statistical } \\
\text { significance } \\
\text { of dietary } \\
\text { effects }\end{array}$} \\
\hline & & & & & & Lin & Quad & Dev \\
\hline Caecal mass (g) & $5 \cdot 9$ & 64 & $6 \cdot 2$ & $5 \cdot 1$ & $0-55$ & NS & NS & NS \\
\hline Caecal tissue (g) & $1 \cdot 1$ & $1 \cdot 2$ & $1 \cdot 0$ & $1 \cdot 0$ & 0.06 & NS & NS & NS \\
\hline Caecal digesta wet wt (g) & $4 \cdot 9$ & $5 \cdot 2$ & $5 \cdot 2$ & $4 \cdot 0$ & $0 \cdot 52$ & NS & NS & NS \\
\hline Proportion of DM in caecal digesta & $0 \cdot 15$ & $0 \cdot 17$ & $0 \cdot 19$ & $0 \cdot 20$ & $0 \cdot 004$ & $* * *$ & NS & NS \\
\hline $\begin{array}{l}\text { Proportion of DM in distal } \\
\text { colonic contents }\end{array}$ & $0 \cdot 40$ & 0.41 & $0 \cdot 42$ & $0 \cdot 37$ & $0 \cdot 030$ & NS & NS & NS \\
\hline
\end{tabular}

NS, not significan1; Lin, Quad and Dev, linear, quadratic and deviations from linear and quadratic effects of wholemeal bread content of diet respectively.

$* * * P<0.001$.

+ For details of diet composition, see Table 1 .

Apparent digestibilities of NSP and of its major components (cellulose and the arabinoxylans) were considerably greater for white bread than for wholemeal bread. This was also true for the minor NSP monomers, mannose and galactose, with an apparent digestibility of zero for the latter in wholemeal bread (Table 5). 
Table 4. Expt 1. pH, total volatile fatty acids (VFA) concentrations (mmol/kg caecal contents) and molar proportions ( $\mathrm{mmol} / \mathrm{mol}$ ) of individual VFA in caeca of rats given diets containing various proportions of white and wholemeal breads

(Means for six rats per diet)

\begin{tabular}{|c|c|c|c|c|c|c|c|c|}
\hline \multirow{2}{*}{$\begin{array}{r}\text { Wholemeal bread in diet }(\mathrm{g} / \mathrm{kg}) \dagger \ldots \\
\text { Diet code } \ldots\end{array}$} & \multirow{2}{*}{$\begin{array}{l}0 \\
W\end{array}$} & \multirow{2}{*}{$\begin{array}{l}300 \\
\text { WB }\end{array}$} & \multirow{2}{*}{$\begin{array}{l}600 \\
\mathrm{BW}\end{array}$} & \multirow{2}{*}{$\begin{array}{c}900 \\
\mathrm{~B}\end{array}$} & \multirow{2}{*}{$\begin{array}{l}\text { SE of } \\
\text { mean }\end{array}$} & \multicolumn{3}{|c|}{$\begin{array}{l}\text { Statistical } \\
\text { significance } \\
\text { of dietary } \\
\text { effects }\end{array}$} \\
\hline & & & & & & Lin & Quad & Dev \\
\hline Caecal pH & 6.] & $6 \cdot 2$ & $6 \cdot 1$ & $6 \cdot 1$ & 0.10 & NS & NS & NS \\
\hline Total VFA (mmol $/ \mathrm{kg}$ caecal contents) & 131 & 125 & 126 & 120 & $5 \cdot 3$ & NS & NS & NS \\
\hline \multicolumn{9}{|l|}{$\begin{array}{l}\text { Molar proportions of individual } \\
\text { VFA }(\mathrm{mmol} / \mathrm{mol})\end{array}$} \\
\hline Acetate & 659 & 602 & 554 & 526 & $19 \cdot 6$ & $* * *$ & NS & NS \\
\hline Propionate & 161 & 171 & 152 & 166 & $6 \cdot 5$ & NS & NS & $*$ \\
\hline Isobutyrate & 6 & 8 & 7 & 10 & $0 \cdot 9$ & * & NS & NS \\
\hline Butyrate & 153 & 196 & 267 & 274 & $20 \cdot 5$ & $* * *$ & NS & NS \\
\hline Isovalerate & 9 & 11 & 9 & 12 & $1 \cdot 0$ & NS & NS & NS \\
\hline Valerate & 12 & 12 & 11 & 12 & 0.5 & NS & NS & NS \\
\hline
\end{tabular}

NS, not significant; Lin, Quad and Dev, linear, quadratic and deviations from linear and quadratic effects of wholemeal bread content of diet respectively.

${ }^{*} P<0.05,{ }^{* * *} P<0.001$.

$\dagger$ For details of diet composition, see Table 1.

Table 5. Expt 1. Apparent digestibilities estimated by multiple linear regression $(M L R)^{*}$ for non-starch polysaccharides (NSP) in white and wholemeal breads when fed in mixed diets to growing rats

(Mean values with their standard crrors; estimates were derived using individual values for all twenty-four rats)

\begin{tabular}{|c|c|c|c|c|c|c|c|}
\hline & \multicolumn{2}{|c|}{ White bread } & \multicolumn{2}{|c|}{ Wholemeal bread } & \multicolumn{2}{|c|}{$\alpha_{3}$} & \multirow[b]{2}{*}{$R^{2}$} \\
\hline & Mean & $\mathrm{SE}$ & Mean & $\mathrm{SE}$ & Mean & $\mathbf{S E}$ & \\
\hline NSP & 0.82 & 0.057 & 0.47 & 0.015 & 0.08 & $0 \cdot 113$ & 0.97 \\
\hline $\mathrm{NCP}$ & 0.85 & 0.047 & 0.52 & 0.014 & -0.13 & 0.090 & 0.97 \\
\hline Cellulose & 0.64 & $0 \cdot 180$ & $0 \cdot 30$ & 0.024 & -0.67 & 0.351 & 0.96 \\
\hline Arabinose & 0.88 & 0.054 & 0.46 & 0.015 & -0.11 & $0 \cdot 103$ & 0.97 \\
\hline Xylose & 0.90 & 0.061 & 0.62 & 0.016 & $-0 \cdot 14$ & 0.116 & 0.94 \\
\hline Mannose & 0.78 & 0.058 & 0.58 & 0.040 & $-0 \cdot 30$ & $0 \cdot 112$ & 0.76 \\
\hline Galactose & 0.47 & 0.045 & -0.06 & 0.032 & $-0-24$ & 0.089 & 0.98 \\
\hline Glucose & 0.75 & 0.093 & $0 \cdot 30$ & 0.022 & -0.28 & $0 \cdot 180$ & 0.97 \\
\hline
\end{tabular}

$\alpha_{3}$, Additional effect of presence of wholemeal bread on indigestibility of NSP fraction in white bread; NCP, non-cellulosic polysaccharides.

* For details of MLR procedures, see Goodlad \& Mathers (1991).

\section{Expt 2}

Food intake and growth. The significantly $(P<0.001)$ lower DM intakes of the high-fat diets (WF and BF) when compared with the low-fat diets (W and $B$ ) were as expected given the difference in amounts of food offered to the two groups (Table 6). The indigestibility 
of DM was significantly greater with the wholemeal-bread diets ( $B$ and $B F$ ) and was unaffected by dietary maize oil concentration. As in Expt 1, faecal $N$ output was significantly increased in rats consuming wholemeal bread; the reduction with the high-fat diets is largely a consequence of reduced $\mathrm{N}$ intake despite the attempt to maintain this across diets by increasing the proportion of casein + amino acids mix in the high-fat diets (Table 1). $\mathrm{N}$ retention was significantly higher for the white-bread (W and WF) than for the wholemeal-bread (B and $\mathrm{BF}$ ) diets.

Caecal fermentation. Rats eating wholemeal-bread-containing diets had significantly heavier caecums containing more digesta and more caecal tissue (Table 7). As in Expt 1, the proportion of DM in caecal digesta of rats consuming white bread was significantly lower than for those consuming wholemeal bread. Whilst there were no significant effects of diet on the proportion of DM in colonic contents (mean 0.40 (SEM 0.013)), there was a tendency for higher values with the high-fat diets. Caecal TT was considerably shorter for wholemeal-bread-containing diets than for white-bread-containing diets $(0.69$ and 0.49 (SEM 0.036 ) d respectively) with no effect of dietary fat content (Table 7).

Flow of DM from the terminal ileum was significantly lower for white-bread-based diets than for wholemeal-bread-based diets and for high-fat diets than for low-fat diets (Table 8). To a large extent the latter difference was due to the planned lower DM intakes with the high-fat diets (Table 6) and when expressed in terms of apparent digestibility at the ileum there was no significant dietary fat effect but a highly significant bread effect (Table 8). The latter effect was still clearly apparent in measurements made on caecal digesta and in faeces. Flows of OM into and from the LB followed the same pattern as for DM flows. An estimate of apparently fermented OM was obtained as the difference between ileal supply and faecal OM. When expressed in absolute terms $(\mathrm{g} / \mathrm{d})$, apparently fermented $\mathrm{OM}$ was significantly lower for animals fed on high-fat diets than for those fed on low-fat diets. However, when expressed as a proportion of ileal OM flow, disappearance of OM in the LB was very significantly higher for rats fed on white bread than for wholemeal bread with no significant effect of dietary fat content.

There were no significant effects of diet on caecal $\mathrm{pH}$ or total VFA concentrations (Table 9). However, as in Expt 1, consumption of wholemeal bread was accompanied by large increases in the molar proportion of butyrate and compensatory decreases in acetate and, in addition, propionate (Expt 2 only). Among the minor VFA only valerate was significantly affected by diet, with lower molar proportions with high-fat intakes especially in conjunction with white bread.

Portal blood acetate concentrations appeared highly variable between animals and, although no significant dietary effects were detected, concentrations tended to be higher with diets $\mathrm{B}$ and BF (Table 10 ). Portal propionate concentrations were, on average, 3.2 and butyrate concentrations $4 \cdot 3$ times higher with the diets containing wholemeal bread than with those containing white bread so that total VFA in portal blood was significantly $(P$ $<0.05)$ greater with diets $\mathrm{B}$ and $\mathrm{BF}$ than with diets $\mathrm{W}$ and WF. Acetate was the only VFA detected in peripheral blood, was not affected by diet and its concentration was, on average, only $40 \%$ of that in portal blood. Concentrations of $3 \mathrm{OHB}$ were very similar in portal and heart blood and, in each case, were significantly $(P<0.001)$ higher with the wholemealbread diets. Dietary fat concentration had no detectable effect on any of the measured blood metabolites.

Digestibility of NSP and of RS. Bread type had a marked effect on apparent digestibility of NSP and all its major constituents with very significantly higher values for white-breadcontaining diets for NSP, NCP, cellulose, arabinose, xylose and glucose (Table 11). The concentration of maize oil in the diet had no significant effect on any of these components, although there was a significant $(P<0 \cdot 001)$ interaction between bread type and maize oil 
Table 6. Expt 2. Effects of bread type and dietary fat content on dry matter (DM) intake and faecal output and aspects of nitrogen $(N)$ metabolism in rats

(Means for six rats per diet)

\begin{tabular}{|c|c|c|c|c|c|c|c|c|}
\hline \multirow[b]{2}{*}{$\begin{array}{r}\text { Maize oil in } \operatorname{diet}(\mathrm{g} / \mathrm{kg}) \dagger \ldots \\
\text { Diet code } \ldots\end{array}$} & \multirow[b]{2}{*}{$\begin{array}{l}30 \\
W\end{array}$} & \multirow[b]{2}{*}{$\begin{array}{l}170 \\
\text { WF }\end{array}$} & \multirow[b]{2}{*}{$\begin{array}{l}30 \\
\mathrm{~B}\end{array}$} & \multirow[b]{2}{*}{$\begin{array}{l}170 \\
\mathrm{BF}\end{array}$} & \multirow[b]{2}{*}{$\begin{array}{l}\mathrm{SE} \text { of } \\
\text { mean }\end{array}$} & \multicolumn{3}{|c|}{$\begin{array}{c}\text { Statistical significance } \\
\text { of dietary effects }\end{array}$} \\
\hline & & & & & & Bread & Fat & $\begin{array}{l}\text { Inter- } \\
\text { action }\end{array}$ \\
\hline DM intake $(g / 7 d)$ & 116 & 105 & 114 & 99 & $3 \cdot 1$ & NS & $* * *$ & NS \\
\hline Faecal DM output $(\mathrm{g} / 7 \mathrm{~d})$ & 5.6 & $5 \cdot 4$ & $12 \cdot 3$ & $10 \cdot 1$ & $0 \cdot 36$ & $* * *$ & $* *$ & $*$ \\
\hline Apparent DM indigestibility & 0048 & 0.051 & $0 \cdot 107$ & 0.102 & 00027 & $* * *$ & NS & NS \\
\hline $\mathrm{N}$ intake $(\mathrm{g} / 7 \mathrm{~d})$ & $2 \cdot 58$ & $2 \cdot 33$ & $2 \cdot 81$ & $2 \cdot 28$ & 0.068 & NS & $* * *$ & NS \\
\hline Faecal $N$ output $(g / 7 d)$ & $0 \cdot 32$ & $0 \cdot 26$ & 0.47 & 0.36 & $0 \cdot 018$ & $* * *$ & $* * *$ & NS \\
\hline Urinary $\mathrm{N}$ output $(\mathrm{g} / 7 \mathrm{~d})$ & $1 \cdot 12$ & 0.94 & $1 \cdot 35$ & 1.01 & $0 \cdot 043$ & $* *$ & $* * *$ & NS \\
\hline$N$ retention $(\mathrm{g} / 7 \mathrm{~d})$ & $1 \cdot 14$ & $1 \cdot 12$ & $1 \cdot 00$ & 0.91 & 0.056 & $* *$ & NS & NS \\
\hline
\end{tabular}

$\mathrm{W}, \mathrm{B}$, white and wholemeal breads respectively; NS, not significant.

${ }^{*} P<0.05,{ }^{* *} P<0.01, * * * P<0.001$.

$\uparrow$ For details of diet composition, see Table 1 .

Table 7. Expt 2. Effects of bread type and dietary fat content on caecal organ, tissue and digesta masses, proportions of dry matter $(D M)$ in caecal and colonic contents and caecal transit time $(T T)$ of rats

(Means for six rats per diet)

\begin{tabular}{|c|c|c|c|c|c|c|c|c|}
\hline \multirow[b]{2}{*}{$\begin{array}{r}\text { Maize oil in } \operatorname{diet}(\mathrm{g} / \mathrm{kg}) \dagger \ldots \\
\text { Diet code } \ldots\end{array}$} & \multirow[b]{2}{*}{$\begin{array}{l}30 \\
W\end{array}$} & \multirow[b]{2}{*}{$\begin{array}{l}170 \\
\text { WF }\end{array}$} & \multirow[b]{2}{*}{$\begin{array}{l}30 \\
\mathrm{~B}\end{array}$} & \multirow[b]{2}{*}{$\begin{array}{l}170 \\
\mathrm{BF}\end{array}$} & \multirow[b]{2}{*}{$\begin{array}{l}\mathrm{SE} \text { of } \\
\text { mean }\end{array}$} & \multicolumn{3}{|c|}{$\begin{array}{l}\text { Statistical significance } \\
\text { of dietary effects }\end{array}$} \\
\hline & & & & & & Bread & Fat & $\begin{array}{l}\text { Inter- } \\
\text { action }\end{array}$ \\
\hline Caecal mass (g) & $4 \cdot 1$ & $3 \cdot 5$ & $4 \cdot 6$ & $4 \cdot 5$ & $0 \cdot 18$ & $* * *$ & NS & NS \\
\hline Caecal tissue (g) & $1 \cdot 0$ & $0 \cdot 9$ & $1 \cdot 1$ & $1 \cdot 1$ & $0 \cdot 04$ & * & NS & NS \\
\hline Caecal digesta wet weight (g) & $3 \cdot 1$ & $2 \cdot 6$ & 3.6 & $3 \cdot 4$ & $0 \cdot 16$ & $* * *$ & $*$ & NS \\
\hline $\begin{array}{l}\text { Proportion of DM in } \\
\text { caecal digesta }\end{array}$ & $0 \cdot 19$ & $0 \cdot 17$ & $0 \cdot 21$ & $0 \cdot 22$ & 0.008 & $* * *$ & NS & NS \\
\hline $\begin{array}{l}\text { Proportion of DM in } \\
\text { colonic contents }\end{array}$ & $0 \cdot 35$ & $0 \cdot 41$ & $0 \cdot 38$ & $0 \cdot 44$ & 0.033 & NS & NS & NS \\
\hline Caecal TT $(\mathrm{d}) \ddagger$ & $0 \cdot 76$ & 0.62 & 0.46 & 0.52 & 0.051 & $* * *$ & NS & NS \\
\hline
\end{tabular}

W, B white and wholemeal breads respectively; NS, not significant.

$* P<0.05$, *** $P<0.001$.

$\uparrow$ For details of diet composition, see Table 1 .

\$ Determined as described by Goodlad \& Mathers (1990).

concentration for the minor sugar mannose where digestibility appeared to increase with the higher fat content for white-bread diets with the opposite occurring for wholemealbread diets. Digestibility of RS (probably mainly retrograded amylose $\left(\mathrm{RS}_{3}\right)$; Englyst \& Kingman, 1990) was not significantly different from unity for all diets except the wholemeal-bread diet with the higher maize oil content where RS digestibility was $0 \cdot 89$. 
Table 8. Expt 2. Effects of bread type and dietary fat content on ileal outputs of dry matter $(D M)$ and organic matter $(O M)$, apparent digestibility of $D M$ at different sites in the intestine and $O M$ disappearance in the large bowel $(L B)$ of rats

(Means for six rats per diet)

\begin{tabular}{|c|c|c|c|c|c|c|c|c|}
\hline \multirow[b]{2}{*}{$\begin{array}{r}\text { Maize oil in } \operatorname{diet}(\mathrm{g} / \mathrm{kg}) \dagger \ldots \\
\text { Diet code } \ldots\end{array}$} & \multirow[b]{2}{*}{$\begin{array}{l}30 \\
W\end{array}$} & \multirow[b]{2}{*}{$\begin{array}{l}170 \\
W F\end{array}$} & \multirow[b]{2}{*}{$\begin{array}{l}30 \\
\mathrm{~B}\end{array}$} & \multirow[b]{2}{*}{$\begin{array}{l}170 \\
\mathrm{BF}\end{array}$} & \multirow[b]{2}{*}{$\begin{array}{l}\text { SE of } \\
\text { mean }\end{array}$} & \multicolumn{3}{|c|}{$\begin{array}{c}\text { Statistical significance } \\
\text { of dietary effects }\end{array}$} \\
\hline & & & & & & Bread & Fat & $\begin{array}{l}\text { Inter- } \\
\text { action }\end{array}$ \\
\hline \multicolumn{9}{|l|}{ Dry matter } \\
\hline Ileal flow $(\mathrm{g} / \mathrm{d})$ & $3 \cdot 7$ & $2 \cdot 7$ & $4 \cdot 5$ & 3.7 & $0 \cdot 33$ & * & $* *$ & NS \\
\hline \multicolumn{9}{|l|}{ Apparent digestibility } \\
\hline $\begin{array}{l}\text { Ileum } \\
\text { Caecum }\end{array}$ & $\begin{array}{l}0.77 \\
0.95\end{array}$ & $\begin{array}{l}0.82 \\
0.95\end{array}$ & $\begin{array}{l}0.73 \\
0.90\end{array}$ & $\begin{array}{l}0.73 \\
0.90\end{array}$ & $\begin{array}{l}0.021 \\
0.004\end{array}$ & $\begin{array}{l}* * \\
* * *\end{array}$ & $\begin{array}{l}\text { NS } \\
\text { NS }\end{array}$ & $\begin{array}{l}\text { NS } \\
\text { NS }\end{array}$ \\
\hline Faeces & 0.96 & 0.95 & 0.90 & 0.91 & 0.001 & $* * *$ & NS & NS \\
\hline \multicolumn{9}{|l|}{ Organic matter } \\
\hline lleal flow $(\mathrm{g} / \mathrm{d})$ & $2 \cdot 2$ & $1 \cdot 5$ & $3 \cdot 4$ & $2 \cdot 7$ & 0.21 & $* * *$ & $* *$ & NS \\
\hline Faecal output (g/d) & 0.6 & $0 \cdot 5$ & 1.6 & $1 \cdot 2$ & 0.04 & $* * *$ & $* * *$ & $* * *$ \\
\hline LB disappearance $(\mathrm{g} / \mathrm{d})$ & 1.6 & $1 \cdot 0$ & 1.9 & $1 \cdot 5$ & $0 \cdot 23$ & NS & $*$ & NS \\
\hline $\begin{array}{l}\text { LB disappearance } \\
\text { (g/g ileal OM flow })\end{array}$ & 0.72 & 0.62 & 0.53 & 0.54 & 0.034 & $* * *$ & NS & NS \\
\hline
\end{tabular}

W, B white and wholemeal breads respectively; NS, not significant.

${ }^{*} P<0.05,{ }^{* *} P<0.01, * * * P<0.001$.

$\dagger$ For details of diet composition, see Table 1.

Table 9. Expt 2. Effects of bread type and dietary fat content on caecal pH, total volatile fatty acids (VFA) and molar proportions (mmol/mol) of individual VFA in rats

(Means for six rats per diet)

\begin{tabular}{|c|c|c|c|c|c|c|c|c|}
\hline \multirow[b]{2}{*}{$\begin{array}{r}\text { Maize oil in diet }(\mathrm{g} / \mathrm{kg}) \dagger \ldots \\
\text { Diet code } \ldots\end{array}$} & \multirow[b]{2}{*}{$\begin{array}{l}30 \\
W\end{array}$} & \multirow[b]{2}{*}{$\begin{array}{l}170 \\
W F\end{array}$} & \multirow[b]{2}{*}{$\begin{array}{c}30 \\
\mathrm{~B}\end{array}$} & \multirow[b]{2}{*}{$\begin{array}{l}170 \\
\mathrm{BF}\end{array}$} & \multirow[b]{2}{*}{$\begin{array}{l}\text { SE of } \\
\text { mean }\end{array}$} & \multicolumn{3}{|c|}{$\begin{array}{l}\text { Statistical significance } \\
\text { of dietary effects }\end{array}$} \\
\hline & & & & & & Bread & Fat & $\begin{array}{l}\text { Inter- } \\
\text { action }\end{array}$ \\
\hline Caecal pH & $6 \cdot 1$ & $6 \cdot 2$ & 6.1 & $6 \cdot 1$ & $0 \cdot 10$ & NS & NS & NS \\
\hline $\begin{array}{l}\text { Total VFA } \\
\text { (mmol/kg caecal contents) }\end{array}$ & 156 & 173 & 158 & 166 & 6.8 & NS & NS & NS \\
\hline \multicolumn{9}{|l|}{$\begin{array}{l}\text { Molar proportions of individual } \\
\text { VFA }(\mathrm{mmol} / \mathrm{mol})\end{array}$} \\
\hline Acetate & 739 & 761 & 602 & 627 & $1 \cdot 3$ & $* * *$ & NS & NS \\
\hline Propionate & 151 & 150 & 110 & 114 & 0.6 & $* * *$ & NS & NS \\
\hline Isobutyrate & 16 & 9 & 11 & 11 & $0 \cdot 2$ & NS & NS & NS \\
\hline Butyrate & 68 & 62 & 252 & 225 & $1 \cdot 4$ & $* * *$ & NS & NS \\
\hline Isovalerate & 11 & 9 & 12 & 11 & $0 \cdot 1$ & NS & NS & NS \\
\hline Valerate & 15 & 9 & 13 & 12 & $0 \cdot 1$ & NS & $* * *$ & $*$ \\
\hline
\end{tabular}

$\mathrm{W}, \mathrm{B}$ white and wholemeal breads respectively; NS, not significant.

$* P<0.05, * * * P<0.001$.

+ For details of diet composition, see Table 1. 
Table 10. Expt 2. Effects of bread type and dietary fat content on concentrations of volatile fatty acids $(V F A ; \mu \mathrm{M})$ and 3-hydroxybutyrate $(3 O H B ; \mu \mathrm{M})$ in blood from the portal vein and heart of rats

(Means for six rats per diet)

\begin{tabular}{|c|c|c|c|c|c|c|c|c|}
\hline \multirow[b]{2}{*}{$\begin{array}{r}\text { Maize oil in diet }(\mathrm{g} / \mathrm{kg}) \dagger \ldots \\
\text { Diet code } \ldots\end{array}$} & \multirow[b]{2}{*}{$\begin{array}{l}30 \\
W\end{array}$} & \multirow[b]{2}{*}{$\begin{array}{l}170 \\
W F\end{array}$} & \multirow[b]{2}{*}{$\begin{array}{l}30 \\
\mathbf{B}\end{array}$} & \multirow[b]{2}{*}{$\begin{array}{l}170 \\
\mathrm{BF}\end{array}$} & \multirow[b]{2}{*}{$\begin{array}{l}\text { SE of } \\
\text { mean }\end{array}$} & \multicolumn{3}{|c|}{$\begin{array}{c}\text { Statistical significance } \\
\text { of dietary effects }\end{array}$} \\
\hline & & & & & & Bread & Fat & $\begin{array}{l}\text { Inter- } \\
\text { action }\end{array}$ \\
\hline \multicolumn{9}{|l|}{ Portal blood } \\
\hline Acetate & 606 & 724 & 926 & 1599 & $304 \cdot 8$ & NS & NS & NS \\
\hline Propionate & 108 & 65 & 219 & 338 & $86 \cdot 7$ & $*$ & NS & NS \\
\hline Butyrate & 18 & 22 & 111 & 59 & $14 \cdot 6$ & $* * *$ & NS & NS \\
\hline Total VFA & 732 & 811 & 1256 & 1996 & $385 \cdot 8$ & $*$ & NS & NS \\
\hline $30 H B$ & 69 & 59 & 122 & 110 & $5 \cdot 7$ & $* * *$ & NS & NS \\
\hline \multicolumn{9}{|l|}{ Heart blood } \\
\hline Acetate & 404 & 366 & 400 & 372 & 28.9 & NS & NS & NS \\
\hline $3 \mathrm{OHB}$ & 71 & 70 & 122 & 110 & $5 \cdot 5$ & $* * *$ & NS & NS \\
\hline
\end{tabular}

W, B white and wholemeal breads respectively; NS, not significant.

$* P<0.05, * * * P<0.001$.

$\dagger$ For details of diet composition, see Table 1 .

Table 11. Expt 2. Apparent digestibilities of non-starch polysaccharides (NSP) and of resistant starch $(R S)$ for white and wholemeal breads in rats given diets of differing dietary fat content with bread providing the only source of complex carbohydrate in these diets

(Means for six rats per diet)

\begin{tabular}{|c|c|c|c|c|c|c|c|c|}
\hline \multirow[b]{2}{*}{$\begin{array}{r}\text { Maize oil in diet }(\mathrm{g} / \mathrm{kg}) \dagger \ldots \\
\text { Diet code.... }\end{array}$} & \multirow[b]{2}{*}{$\begin{array}{l}30 \\
W\end{array}$} & \multirow[b]{2}{*}{$\begin{array}{l}170 \\
W F\end{array}$} & \multirow[b]{2}{*}{$\begin{array}{l}30 \\
\mathbf{B}\end{array}$} & \multirow[b]{2}{*}{$\begin{array}{l}170 \\
\mathrm{BF}\end{array}$} & \multirow[b]{2}{*}{$\begin{array}{l}\text { SE of } \\
\text { mean }\end{array}$} & \multicolumn{3}{|c|}{$\begin{array}{l}\text { Statistical significance } \\
\text { of dietary effects }\end{array}$} \\
\hline & & & & & & Bread & Fat & $\begin{array}{l}\text { Inter- } \\
\text { action }\end{array}$ \\
\hline NSP & 0.77 & $0 \cdot 81$ & 0.52 & $0 \cdot 50$ & $0 \cdot 018$ & $* * *$ & NS & NS \\
\hline NCP & 0.80 & 0.84 & 0.60 & 0.58 & 0.015 & $* * *$ & NS & NS \\
\hline Cellulose & 0.49 & 0.48 & 0.20 & $0 \cdot 13$ & 0.043 & $* * *$ & NS & NS \\
\hline Arabinose & 0.85 & 0.89 & 0.47 & 0.48 & 0.017 & $* * *$ & NS & NS \\
\hline Xylose & 0.87 & 0.90 & 0.63 & 0.63 & $0 \cdot 016$ & $* * *$ & NS & NS \\
\hline Mannose & 0.52 & 0.78 & 0.71 & 0.59 & 0.041 & NS & NS & $* * *$ \\
\hline Galactose & $0 \cdot 27$ & $0 \cdot 29$ & $0 \cdot 31$ & 0.35 & 0.043 & NS & NS & NS \\
\hline Glucose & 0.74 & 0.74 & 0.41 & 0.34 & 0.027 & $* * *$ & $\mathrm{NS}$ & NS \\
\hline RS & 0.99 & 0.99 & 1.05 & 0.89 & 0.027 & NS & $*$ & $* *$ \\
\hline
\end{tabular}

W, B white and wholemeal breads respectively; NCP, non-cellulosic polysaccharides; NS, not significant.

$* P<0.05,{ }^{* *} P<0.01, * * * P<0.001$

$\dagger$ For details of diet composition, see Table 1 .

\section{DISCUSSION}

Determination of the digestibility of individual foods or ingredients in man presents a major problem in that, with the exception of unweaned infants, mixed diets are habitually eaten and the consumption of only a single food for the time necessary to obtain reliable estimates of digestibility is impractical. One possible solution to this problem is to supply 
the test food or ingredient in addition to a basal diet and to attribute any additional faecal material to the indigestible fraction of the test food (van Dokkum et al. 1983; Stephen et al. 1986). This assumes, implicitly or explicitly, that the addition of the test food has no effect on the digestibility of the basal diet (or vice versa), i.e. that there are no associative effects; an assumption, with uncertain validity, which has long been recognized (see Macrae et al. 1942). An alternative approach, used for example by Macrae et al. (1942) and McCance \& Walsham (1948), is to arrange that the test foodstuff makes up as much as possible of the experimental diets and that the other components (necessary for palatability or to ensure nutritional adequacy) contain a minimum of the nutrients under investigation. For example, in the studies of Macrae et al. (1942) bread contributed 74 and $90 \%$ of the energy and $\mathrm{N}$ intakes respectively and virtually all the complex carbohydrates, whilst in the studies of McCance \& Widdowson (1942a) bread provided 40-50\% of energy and most of the calcium, the main mineral under investigation. In calculating apparent digestibilities, Macrae et al. (1942) attributed all the faecal output to the breads under test whilst McCance \& Widdowson (1942a) and McCance \& Walsham (1948) referred to digestibilities of particular diets rather than to the individual breads which were their largest components.

In our experimental diets, bread, either white or wholemeal, provided all the complex carbohydrates and approximately $90 \%$ of DM intake. For Expt 1, where we made a direct comparison of the two types of bread, the other diet ingredients remained constant so that changes in faecal carbohydrate output could be strictly attributed to the breads being investigated. The feeding of such defined and uniform diets to rats over a sufficiently long period can produce both precise and accurate estimates of the digestibility of bread NSP. Whilst such estimates obtained in the rat may also apply to man (Nyman et al. 1986), there have been insufficient direct between-species comparisons to permit the unequivocal assumption that results from one species will always apply to the other (for discussion, see Mathers, 1991).

Digestibility of complex carbohydrates. Direct comparison of the results from the present study with those in the literature on the digestibility of complex carbohydrates in breads are complicated, not only by problems of experimental protocol but also by differences in the methods used to determine the non-starch fraction of the polysaccharides. Early studies by, for example, Macrae et al. (1942) and McCance \& Walsham (1948) used the unphysiological 'crude fibre' method whilst van Dokkum et al. (1983) used van Soest's detergent-gravimetric methods (van Soest \& Wine, 1967). The most comparable study is that by Ranhotra et al. (1988) who, using the 'dietary fibre' method of Prosky et al. (1984), obtained digestibilities of 82 and $44 \%$ for white and wholemeal breads respectively in the rat. These are similar to the values for NSP digestibility of $77-82 \%$ for white bread, and $47-52 \%$ for wholemeal bread obtained in our experiment (Tables 5 and 11). Apparent digestibility of NSP in a white-bread-based diet consumed by human volunteers was $78 \%$ with a calculated digestibility of only $33 \%$ (range $0-62 \%$ ) for wheat bran added to the basal diet (Stephen et al. 1986).

Starch which escapes small intestinal digestion (RS) is subject to fermentation by the LB flora (Macfarlane \& Englyst, 1986). Our breads, in agreement with the results of Englyst $\&$ Cummings (1984), contained some starch which was resistant to pancreatic $\alpha$-amylase (EC 3.2.1.1) without previous treatment with DMSO and was probably present as $\mathrm{RS}_{3}$ (Englyst \& Kingman, 1990). This fraction disappeared almost entirely during passage through the gut for all diets except the wholemeal-bread diet containing $170 \mathrm{~g}$ maize oil $/ \mathrm{kg}$ (BF; Table 11). The appearance of starch in the faeces of some subjects eating both white and bran-enriched breads was reported by Stephen et al. (1986). In an earlier study (Goodlad \& Mathers, 1991) we were unable to detect RS in the faeces of rats given raw or cooked peas (Pisum sativum) in contrast to the results of Faulks et al. (1989). Given the 
recent recognition of RS as an important food component (Englyst \& Cummings, 1987) and the limited studies on its digestibility, it would be unsafe to assume that all dietary RS is fermented in the LB.

Knowledge of the digestibility of NSP and of RS is of practical value since this is the primary determinant of the energy value of these carbohydrate fractions (Livesey, 1990; Mathers, 1991). Current food tables (Paul \& Southgate, 1978), whilst recognizing that NSP may be fermented and produce VFA which are absorbed, discount the energy value of this fraction because of compensatory increases in faecal excretion of fat and protein when diets rich in NSP are consumed (Southgate \& Durnin, 1970). However, reappraisal of published results (Livesey, 1990) and the development of models to estimate energy gain from NSP digestion in the LB (e.g. Mathers, 1991) suggest that nutritionally important amounts of energy may be salvaged by LB fermentation. If this is so then quantitative information on the digestibility of NSP, especially for NSP-rich foods, may be of value in compilations of the energy values of foods.

Associative effects on digestibility. When two or more foods or ingredients are consumed together it is possible that the digestibilities of this mixture will not be the weighted sum of the digestibilities of the individual dietary components, i.e. that there may be associative effects. In a recent extensive series of studies with rats fed on mixtures of cereal- and legume-based foods, Hansen et al. (1991) reported that whilst, in most cases, digestibility coefficients (DC) for such mixtures can be calculated with high precision for DM, energy, protein, starch and 'dietary fibre' from DC values for individual ingredients, where mixtures contained large amounts of soluble 'dietary fibre' measured DC for the latter fraction may be considerably lower than calculated values. Goodlad \& Mathers (1991) found no evidence for associative effects in digestibility of NSP in pigs given wheat-based diets containing 0-300 $\mathrm{g}$ raw peas $/ \mathrm{kg}$. Similarly, there were no detectable associative effects for NSP digestibility between white and wholemeal breads in the present study. The apparent interaction between bread type and dietary maize oil concentration in digestibility of mannose (Table 11) may be real but is unlikely to have any nutritional significance given the small concentration of mannose in bread NSP. In the absence of anti-nutritional factors influencing host digestive enzyme action or absorption, or of dietary substances affecting the activity of the LB flora, it seems unlikely that there will be important associative effects for common human foods. However, substances which influence TT through the LB may have an impact on the apparent digestibility of NSP (Stephen et al. 1987) with consequential effects on the energy yield from this carbohydrate fraction (Mathers, 1991).

$L B$ fermentation. The most striking effect on LB fermentation of replacing white by wholemeal bread was the large increase in molar proportion of butyrate in caecal VFA largely at the expense of acetate (Tables 4 and 9). It is of interest that these changes were linear with respect to changes in proportions of white and wholemeal breads (Table 4). Similar linearity in response of caecal VFA pattern was reported for addition of peas to a basal NSP-free diet by Goodlad \& Mathers (1990). We have no satisfactory explanation for the greater increase in butyrate in Expt 2, although it should be noted that it is largely due to a much lower butyrate molar proportion with white bread in Expt 2 when compared with Expt 1. Clearly this change in pattern of fermentation endproducts is associated with a substantial alteration in the chemical composition and amount of substrate delivered to the caecum from the terminal ileum (Table 8) and it might be argued that more NSP per se may induce changes in bacterial metabolism. Certainly there is evidence that rat caecal VFA pattern is readily altered by increases in NSP intake with high butyrate proportions reported with cereal sources of NSP (Cheng et al. 1987; Mathers et al. 1990). However, we have argued elsewhere that substrate supply may not necessarily be the only or indeed the 
major influence on fermentation pattern (Goodlad \& Mathers, 1990). The proportion of butyrate may be influenced by caecal TT showing sharp increases below TT of $0.60 .7 \mathrm{~d}$ (Mathers \& Dawson, 1991). In Expt 2 caecal TT fell from, on average, 0.69 d with the white-bread diets to $0.49 \mathrm{~d}$ with the wholemeal-bread diets (Table 7) as would be expected from the greater intake of NSP with the latter diet (van Dokkum et al. 1983; Stephen et al. 1986). The importance or otherwise of caecal TT in determining VFA pattern might be resolved by investigating the effects of pharmacological alteration of TT with no change in NSP intake (see Stephen et al. 1987).

For the rats in Expt 2 the amount of OM fermented in the LB was not affected by bread type but because there was more OM delivered to the LB with the wholemeal-bread diets, the fraction of ileal OM apparently fermented in the LB was significantly lower for the latter diets (Table 8). Therefore, although the wholemeal-bread diets provided much greater intakes of NSP and more OM flowing to the LB than did the white-bread diets, where was no between-diet difference in estimated VFA absorption from the LB (F. B. Key \& J. C. Mathers, unpublished results). If all the ingested NSP flowed to the LB (Englyst \& Cummings, 1985) then this carbohydrate fraction accounted for $0.15-0.37$ of the OM leaving the terminal ileum and $0 \cdot 16-0 \cdot 35$ of the OM apparently fermented in the LB. Other food components and endogenous materials clearly play a significant part in this aspect of LB metabolism (Cummings \& Englyst, 1987).

The relative lack of effect of dietary maize oil on caecal fermentation (including the digestibility of NSP) is probably due to the high digestibility of triacylglycerols in the small bowel so that only small amounts of fat appear in ileal effluent (McNeil et al. 1982) even in subjects with relatively high intakes (Higham \& Read, 1990). An intriguing report of reduced methane production with soya-bean oil addition to the diet (independent of changes in non-fat intake) has been reported for the pig by Christensen \& Thorbek (1987), whilst Mallett et al. (1983) found that very-high-fat diets $(350 \mathrm{~g} / \mathrm{kg})$ fed to rats, in general, decreased the activities of caecal microbial enzymes. No mechanisms for these effects have been established and it is possible that the effects are indirect and occur via bacteriostatic effects of additional bile salts flowing to the LB in response to the additional triacylglycerol intake.

\section{Conclusion}

There were no important associative effects between type of bread in the diet or dietary maize oil concentration on digestibility of NSP or on caecal fermentation pattern. Increasing NSP intake by replacing white bread with wholemeal bread in the diet of rats provoked large increases in caecal butyrate molar proportion which could not be explained by the amount of OM fermented in the LB.

F.B.K. held an AFRC Food Research Studentship whilst the studies were carried out.

\section{REFERENCES}

Cheng, B.-Q., Trimble, R. P., Illman, R. J., Stone, B. A. \& Topping, D. L. (1987). Comparative effects of dietary wheat bran and its morphological components (aleurone and pericarp-seed coat) on volatile fatty acid concentrations in the rat. British Journal of Nutrition 57, 69-76.

Christensen, K. \& Thorbek, G. (1987). Methane excretion in the growing pig. British Journal of Nutrition 57, 355-361.

Cummings, J. H. \& Englyst, H. N. (1987). Fermentation in the human large intestine and the available substrates. American Journal of Clinical Nutrition 45, 1243-1255.

Department of Health and Social Security (1984). Diet and Cardiovascular Disease. Report of the Committee on Medical Aspects of Food Policy. London: H.M. Stationery Office. 
Englyst, H. N. \& Cummings, J. H. (1984). Simplified method for the measurement of total non-starch polysaccharides by gas-liquid chromatography of constituent sugars as the alditol acetates. Analyst 109, 937-942.

Englyst, H. N. \& Cummings, J. H. (1985). Digestion of the polysaccharides of some cereal foods in the human small intestine. American Journal of Clinical Nutrition 42, 778-787.

Englyst, H. N. \& Cummings, J. H. (1987). Resistant starch, a 'new' food component: a classification of starch for nutritional purposes. In Cereals in a European Context, pp. 221-233 [I. D. Morton, editor]. Chichester: Ellis Horwood.

Englyst, H. N. \& Kingman, S. M. (1990). Dietary fiber and resistant starch. A nutritional classification of plant polysaccharides. In Dietary Fiber, pp. 49-65 [D. Kritchevsky, C. Bonfield and J. W. Anderson, editors]. New York: Plenum Publishing Corporation.

Faulks, R. M., Southon, S. \& Livesey, G. (1989). Utilization of $\alpha$-amylase (EC 3.2.1 1)-resistant maize and pea (Pisum sativum) starch in the rat. British Journal of Nutrition 61, 291-300.

Goodlad, J. S. \& Mathers, J. C. (1990). Large bowel fermentation in rats given diets containing raw peas (Pisum sativum). British Journal of Nutrition 64, 569-587.

Goodlad, J. S. \& Mathers, J. C. (1991). Digestion by pigs of non-starch polysaccharides in wheat and raw peas (Pisum sativum) fed in mixed diets. British Journal of Nutrition 65, 259-270.

Hansen, I., Larsen, T., Bach Knudsen, K. E. \& Eggum, B. O. (1991). Nutrient digestibilities in ingredients fed alone or in combinations. British Journal of Nutrition 66, 27-35.

Higham, S. E. \& Read, N. W. (1990). Effect of ingestion of fat on ileostomy effluent. Gut 31, 435-438.

Key, F. B. \& Mathers, J. C. (1987). Response of rat caecal metabolism to varying proportions of white and wholemeal breads. Proceedings of the Nutrition Society 46, $11 \mathrm{~A}$.

Key, F. B. \& Mathers, J. C. (1988). Response of rat caecal metabolism to white and wholemeal breads given at two fat levels. Proceedings of the Nutrition Society 47, 101A.

Key, F. B. \& Mathers, J. C. (1990). Estimation of the digestibilities of NSP for wholemeal bread and haricot beans fed in mixed diets. In Dietary Fibre: Chemical and Biological Aspects, pp. 254-258 [D. A. T. Southgate, K. Waldron, I. T. Johnson and G. R. Fenwick, editors]. Cambridge: Royal Society of Chemistry.

Livesey, G. (1990). Energy values of unavailable carbohydrate and diets: an enquiry and analysis. American Journal of Clinical Nutrition 51, 617-637.

Lloyd, B., Burrin, J., Smythe, P. \& Alberti, K. G. M. M. (1978). Enzymic fluorimetric continuous flow assays for blood glucose, lactate, pyruvate, alanine, glycerol and 3-hydroxybutyrate. Clinical Chemistry 34, 1724-1729.

McCance, R. A. \& Walsham, C. M. (1948). The digestibility and absorption of the calories, proteins, purines, fat and calcium in wholemeal wheaten bread. British Journal of Nutrition 2, 26-41.

McCance, R. A. \& Widdowson, E. M. (1942a). Mineral metabolism of healthy adults on white and brown bread dietaries. Journal of Physiology 101, 44-85.

McCance, R. A. \& Widdowson, E. M. (1942b). Mineral metabolism on dephytinized bread. Journal of Physiology 101, 304-313.

Macfarlane, G. T. \& Englyst, H. N. (1986). Starch utilization by the human large intestinal microflora. Journal of Applied Bacteriology 60, 195-201.

McNeil, N. I., Bingham, S., Cole, T. J., Grant, A. M. \& Cummings, J. H. (1982). Diet and health of people with an ileostomy. 2. Ileostomy function and nutritional state. British Journal of Nutrition 47, 407-415.

Macrae, T. F., Hutchinson, J. C. D., Irwin, J. O., Bacon, J. S. D. \& McDougall, E. I. (1942). Comparative digestibility of wholemeal and white breads and the effect of the degree of fineness of grinding of the former. Journal of Hygiene 42, 423-435.

Mallett, A. K., Rowland, I. R. \& Wise, A. (1983). Influence of dietary fats on rat caecal microflora. Proceedings of the Nutrition Society $\mathbf{4 3}, 7 \mathrm{~A}$.

Mathers, J. C. (1991). Digestion of non-starch polysaccharides by non-ruminant omnivores. Proceedings of the Nutrition Society 50, 161-172.

Mathers, J. C. \& Dawson, L. D. (1991). Large bowel fermentation in rats eating processed potatoes. British Journal of Nutrition 66, 313-329.

Mathers, J. C, Fernandez, F., Hill, M. J., McCarthy, P. T., Shearer, M. J. \& Oxley, A. (1990). Dietary modification of potential vitamin $\mathrm{K}$ supply from enteric bacterial menaquinones in rats. British Journal of Nutrition 63, 639-652.

Nyman, M., Asp, N.-G., Cummings, J. \& Wiggins, H. (1986). Fermentation of dietary fibre in the intestinal tract: comparison between man and rat. British Journal of Nutrition 55, 487-496.

Paul, A. A. \& Southgate, D. A. T. (1978), McCance and Widdowson's The Composition of Foods, 4th revised ed. London: H.M. Stationery Office.

Prosky, L., Asp, N. G., Furda, I., Devries, J. W., Schweizer, T. F. \& Harland, B. F. (1984). Determination of total dietary fibre in foods, food products and total diets: interlaboratory study. Journal of the Association of Official Analytical Chemists 67, 1044-1051.

Ranhotra, G. S., Gelroth, J. A. \& Bright, P. H. (1988). Effect of the source of fiber in bread on intestinal responses and nutrient digestibilities. Cereal Chemistry $65,9-12$

Southgate, D. A. T. (1969). Determination of carbohydrate in foods. II. Unavailable carbohydrate. Journal of the Science of Food and Agriculture 20, 331-339. 
Southgate, D. A. T. \& Durnin, J. V. G. A. (1970). Calorie conversion factors. An experimental reassessment of the factors used in the calculation of the energy value of human diets. British Journal of Nutrition 24, 517-521.

Stephen, A. M., Wiggins, H. S. \& Cummings, J. H. (1987). Effects of changing transit time on colonic microbial metabolism in man. Gut 28, 601-609.

Stephen, A. M., Wiggins, H. S., Englyst, H. N., Cole, T. J., Wayman, B. J. \& Cummings, J. H. (1986). The effect of age, sex and level of intake of dietary fibre from wheat on large-bowel function in thirty healthy subjects. British Journal of Nutrition 56, 349-361.

Thompson, A. (1970). Rat metabolism cage. Journal of the Institute of Animal Technicians 21, 12-21.

Van Dokkum, W., Pikaar, N. A. \& Thissen, J. T. N. M. (1983). Physiological effects of fibre-rich types of bread. 2. Dietary fibre from bread: digestibility by the intestinal microflora and water-holding capacity in the colon of human subjects. British Journal of Nutrition 50, 61-74.

Van Soest, P. J. \& Wine, R. H. (1967). Use of detergents in the analysis of fibrous feeds. IV. Determination of cell wall constituents. Journal of the Association of Official Analytical Chemists 50, 50-55.

Zar, J. H. (1974). Biostatistical Analysis, p. 257. Englewood Cliffs, N.J.: Prentice-Hall. 